\title{
EXAMINATION FOR POSTERIOR SUBCAPSULAR CATARACTS IN PATIENTS TREATED WITH TOPICAL STEROIDS* ${ }^{\dagger}$
}

\author{
BY \\ JOHN WILLIAMSON \\ Ophthalmic Institute, Glasgow Royal Infirmary \\ AND \\ M. K. JASANI \\ Centre for Rheumatic Diseases, Glasgow
}

A FEW reports have appeared in the literature suggesting that long-term topical steroids may be associated with the development of posterior subcapsular cataract in the treated eye(s) (Valerio, 1963; Cronin, 1964; Streiff, 1964; Becker, 1964; Crews, 1965).

Cronin (1964) described unilateral posterior subcapsular cataract in a 19-year-old male treated for one year with topical steroids and Idoxuridine 0.1 per cent. for dendritic keratitis. No uveitis was detected. He was unable to decide whether the steroid itself, the Idoxuridine, or a combination of both was responsible. Streiff (1964) described anterior and posterior subcapsular changes after 8 months' treatment with topical steroids in a 24-year-old male suffering from hay fever and allergic conjunctivitis.

It was therefore decided to examine a number of patients attending the outpatients department who were being treated with betamethasone disodium phosphate 0.1 per cent. in a water-miscible base or betamethasone disodium phosphate 0.1 per cent. and neomycin sulphate B.P. 0.5 per cent. in a water-miscible base, or who had been treated with these substances (Betnesol or Betnesol-N., Glaxo Laboratories) during the past 2 years, for not less than 2 months. None of the patients was or had been treated with systemic steroids.

\section{Material and Methods}

87 patients (136 eyes) attended a series of special clinics for review. Table I shows the age and sex distribution; mean age 50.5 years (range 15 to 78 ).

TABLE I

Age AND Sex of 87 Patients

\begin{tabular}{c|c|c|c|c|c|c|c|c}
\hline \multicolumn{2}{c|}{ Age Group (yrs) } & Total & $15-25$ & $25-35$ & $35-45$ & $45-55$ & $55-65$ & $65+$ \\
\hline Sex & Male & 34 & 4 & 1 & 6 & 5 & 9 & 9 \\
& Female & 53 & 5 & 5 & 8 & 7 & 12 & 16 \\
\hline & Total & 87 & 9 & 6 & 14 & 12 & 21 & 25 \\
\hline
\end{tabular}

* Received for publication May 10, 1966

+ Address for reprints: Department of Ophthalmology, Southern General Hospital, Glasgow. 
Table II shows the disease diagnosed before treatment was commenced and the duration of topical steroid therapy.

TABLE II

DiAGNOSIS IN 136 EYES

\begin{tabular}{|c|c|c|c|c|c|}
\hline \multirow{2}{*}{\multicolumn{2}{|c|}{ Diagnosis }} & \multirow{2}{*}{$\begin{array}{l}\text { No. of } \\
\text { Eyes }\end{array}$} & \multicolumn{3}{|c|}{ Duration of Treatment (mths) } \\
\hline & & & $2-6$ & $6-12$ & $12+$ \\
\hline \multicolumn{2}{|c|}{$\begin{array}{l}\text { Conjunctivitis } \\
\text { Blepharo-conjunctivitis } \\
\text { Keratitis (various types) } \\
\text { Anterior uveitis } \\
\text { Episcleritis } \\
\text { Herpes zoster ophthalmicus } \\
\text { Styes } \\
\text { Fuchs's endothelial dystrophy } \\
\text { Perforating wound } \\
\text { Corneal laceration }\end{array}$} & $\begin{array}{r}45 \\
23 \\
30 \\
20 \\
8 \\
2 \\
4 \\
2 \\
1 \\
1\end{array}$ & $\begin{array}{r}36 \\
19 \\
10 \\
8 \\
6 \\
4 \\
1 \\
1\end{array}$ & $\begin{array}{l}4 \\
2 \\
7 \\
4 \\
1 \\
1\end{array}$ & $\begin{array}{r}5 \\
2 \\
13 \\
8 \\
1 \\
1 \\
2\end{array}$ \\
\hline \multirow{2}{*}{ Total } & No. & 136 & 85 & 19 & 32 \\
\hline & Per cent. & 100 & $62 \cdot 0$ & $14 \cdot 7$ & $23 \cdot 3$ \\
\hline
\end{tabular}

The patients' pupils were dilated with homatropine 1 per cent. and cocaine 2 per cent. and the lenses were examined by means of a modern Zeiss slit lamp.

\section{Results}

Only two cases of posterior subcapsular cataract were detected: one in a case of episcleritis in which it had been noted before treatment, and the other in a patient suffering from anterior uveitis. The latter finally developed complete cataract, a not unusual occurrence in this disease in any case.

Table III shows what happened to the cases of anterior uveitis, a condition in which one might expect the development of posterior subcapsular and posterior cortical opacities. Only one of the twenty cases developed these lens opacities and very soon a complete cataract had formed. It is particularly interesting to note that none of the eight eyes treated for more than one year developed posterior subcapsular cataract and that five of them showed no opacities at all. In fact, three eyes had been treated for more than 3 years and yet remained quite clear.

TABLE III

INCIDENCE OF LENS OPACITIES

\begin{tabular}{c|c|c|ll}
\hline $\begin{array}{c}\text { Duration of } \\
\text { Treatment } \\
\text { (mths) }\end{array}$ & $\begin{array}{c}\text { No. of } \\
\text { Eyes }\end{array}$ & \multicolumn{4}{|c}{ Incidence of Lens Opacities (excluding congenital) } \\
\cline { 2 - 5 } & 8 & Clear & \multicolumn{1}{c}{ Cataract } \\
\hline $2-6$ & 4 & $\begin{array}{l}1 \text { anterior subcapsular and cortical } \\
1 \text { peripheral senile } \\
2 \text { nuclear sclerosis and senile cortical }\end{array}$ & 4 \\
\hline $6-12$ & 4 & 0 & $\begin{array}{l}1 \text { anterior cortical, nasal side only } \\
1 \text { complete cataract } \\
2 \text { nuclear sclerosis }\end{array}$ & 4 \\
\hline $12+$ & 8 & 5 & $\begin{array}{l}2 \text { anterior subcapsular and cortical } \\
1 \text { anterior subcapsular and nuclear sclerosis }\end{array}$ & 3 \\
\hline
\end{tabular}




\section{Summary}

136 eyes treated with Betnesol or Betnesol-N. drops or ointment at least twice daily for various lengths of time in excess of 2 months were examined for posterior subcapsular cataract. Two cases were detected. In one the cataract had been present before treatment, and the other was a case of uveitis. Attention is drawn to the fact that, of eight eyes treated for uveitis for more than one year, five showed no opacities whatsoever and three of these had been treated for 3 years or more.

\section{REFERENCES}

BeCKER, B. (1964). Invest. Ophthal., 3, 492.

Crews, S. J. (1965). Proc. roy. Soc. Med., 58, 533.

Cronin, T. P. (1964). Arch. Ophthal. (Chicago), 72, 198.

StREIFF, E. B. (1964). Ophthalmologica (Basel), $147,143$.

VALERIO, M. (1963). Bull. Soc. frans. Ophtal., 76, 572. 